\title{
BENZIMIDAZOLE AND ITS DERIVATIVES AS CORROSION INHIBITORS FOR MILD STEEL IN HYDROCHLORIC ACID
}

\author{
BENZIMIDAZOL IN NJEGOVI DERIVATI KOT ZAVIRALCI \\ KOROZIJE MALOLEGIRANEGA JEKLA V SOLNI KISLINI
}

\author{
Zhaolei Li ${ }^{1,2}$, Deng Wang ${ }^{1}$, Bojun He${ }^{1}$, Xinxin Ye ${ }^{1}$, Weijie Guo ${ }^{1}$ \\ ${ }^{1}$ Jiangsu University of Science and Technology, National Demonstration Center for Experimental Materials Science and Engineering \\ Education, School of Materials Science and Engineering, 2 Mengxi Road, 212003 Zhenjiang, China \\ 2Jiangsu Sidike New Materials Science and Technology Co. Ltd., Suzhou 215400, China \\ zllinju@126.com \\ Prejem rokopisa - received: 2017-09-04; sprejem za objavo - accepted for publication: 2017-11-03
}

doi:10.17222/mit.2017.145

\begin{abstract}
Using potentiodynamic polarization curves and electrochemical impedance spectroscopy (EIS), the inhibition ability of benzimidazole $(\mathrm{BI}), 2$-methylthiobenzimidazole (2-MBI) and 2-chloromethylbenzimidazole (2-CBI) for mild steel in an $\mathrm{HCl}$ solution $\left(1 \mathrm{~mol} \mathrm{~L}^{-1}\right)$ was investigated. With an increase in the concentration, 2-MBI showed the highest inhibition efficiency (IE) at $1.24 \times 10^{-3} \mathrm{~mol} \mathrm{~L}^{-1}$, while the IE of BI and 2-CBI increased continuously within the investigated concentration range. The IE increased in the order of $\mathrm{BI}<2-\mathrm{MBI}<2-\mathrm{CBI}$, which was further confirmed by the morphologies of the mild-steel surfaces after their immersion in $1 \mathrm{M} \mathrm{HCl}$ with or without different inhibitors. Fitted adsorption isotherm curves suggested that the adsorption of the three inhibitors onto the mild steel in $1 \mathrm{M} \mathrm{HCl}$ follow the Langmuir adsorption isotherm. Considering the effects of the temperature on the adsorption behaviour of the inhibitors, the apparent activation energy $\left(E_{\mathrm{a}}\right)$ of the mild-steel corrosion in the $\mathrm{HCl}$ solution with BI, 2-MBI and 2-CBI was calculated as $(42.00,48.28$ and 67.93$) \mathrm{kJ} \mathrm{mol}^{-1}$, respectively.
\end{abstract}

Keywords: mild steel, benzimidazole derivatives, inhibitor, adsorption

V članku avtorji opisujejo raziskavo sposobnosti benzimidazolovih derivatov: benzimidazola (BI), 2-metiltiobenzimidazola (2-MBI) in 2-klorometilbenzimidazola (2-CBI) za zaviranje korozije malolegiranega ( $\mathrm{z}$ nizko vsebnostjo ogljika) jekla v raztopini $\left(1 \mathrm{~mol} \mathrm{~L}^{-1}\right)$ solne kisline. V raziskavi so za to uporabili potenciodinamične polarizacijske krivulje in elektrokemično impedančno spektroskopijo (EIS). Kot najučinkovitejši zaviralec (IE; angl.: Inhibition Efficiency) se je z naraščajočo koncentracijo pri $1,24 \times 10^{-3} \mathrm{~mol} \mathrm{~L}^{-1}$ izkazal 2-MBI, medtem ko je zaviralna učinkovitost BI in 2-CBI naraščala zvezno v preiskovanem območju koncentracij. IE je naraščala v smeri $\mathrm{BI}<2-\mathrm{MBI}<2-\mathrm{CBI}$, ki so jo nadalje potrdili s preiskavami morfologije površine malolegiranega jekla po potapljanju v $1 \mathrm{M}$ raztopino $\mathrm{HCl} v$ ali brez prisotnosti izbranih zaviralcev. Zglajene adsorpsijske izotermalne krivulje kažejo na to, da izbrani zaviralci na malolegiranem jeklu v $1 \mathrm{M} \mathrm{HCl} \mathrm{sledijo} \mathrm{Langmuir-jevi} \mathrm{adsorpcijski}$ izotermi. Avtorji prispevka so, upoštevajoč vpliv temperature, izračunali navidezne aktivacijske energije $\left(E_{\mathrm{a}}\right)$ korozije malolegiranega jekla v raztopini $\mathrm{HCl}$ s prisotnostjo $\mathrm{BI}, 2-\mathrm{MBI}$ in 2-CBI. Izračunane vrednosti $E_{\mathrm{a}}$ so bile $(42,00,48,28$ in 67,93$)$ $\mathrm{kJ} \mathrm{mol}^{-1}$.

Ključne besede: malolegirano jeklo, derivati benzimidazola, zaviralec, adsorpcija

\section{INTRODUCTION}

Corrosion behaviours of metals can be observed in different fields of industry, causing significant economic losses. ${ }^{1-3}$ Using corrosion inhibitors is one of the most efficient and economical methods for the protection of metals and their alloys against corrosion, especially in acidic solutions. ${ }^{4-6}$ Organic compounds with $\pi$ electrons and heteroatoms such as $\mathrm{O}, \mathrm{N}, \mathrm{S}$ proved to be the most effective corrosion inhibitors. ${ }^{7-10}$ The electrostatic physisorption or chemisorption ascribed to the transformation of electrons from inhibitors to the metal surface are considered to be the reasons why inhibitors can retard the corrosion behaviour. However, the relationship between the molecular structure and the inhibition efficiency (IE) has not yet been completely established.

Benzimidazole (BI) and its derivatives were used to inhibit the corrosion of metals in a corrosive medium. ${ }^{11-18} \mathrm{~J}$. Aljourani et al. ${ }^{11}$ researched the BI, 2-methylbenzimidazole and 2-mercaptobenzimidazole as corro- sion inhibitors for mild steel in the $1 \mathrm{M} \mathrm{HCl}$ solution; they found that these inhibitors retarded both the cathodic and anodic processes and that the inhibition efficiency was increased with an inhibitor concentration in the order of 2-mercaptobenzimidazole > 2-methylbenzimidazole > BI. Recently, P. Morales-Gil et al. ${ }^{19}$ found that the IE of 2-mercaptobenzimidazole for carbon steel in the $1 \mathrm{M}$ hydrochloric acid is $99 \%$, with a concentration of $2 \mathrm{mM}$. K. F. Khaled ${ }^{20}$ reported the corrosion inhibition of iron in $1.0 \mathrm{M} \mathrm{HNO}_{3}$ due to some benzimidazole derivatives where the IE increased in the order of 2-methylthiobenzimidazole $(2-\mathrm{MBI})<2$-chloromethylbenzimidazole $(2-\mathrm{CBI})<2$-aminomethylbenzimidazole (2-ABI), since 2-ABI has a higher HOMO energy and larger number of electrons transferred to the iron surface $(\Delta N)$ than that of the other two. 2-CBI was also used as the inhibitor for the carbon steel in $1 \mathrm{M} \mathrm{HCl}$, and it showed the highest IE among the involved six compounds, including imidazole, benzimidazole, pyridine and their derivatives. ${ }^{21}$ 
However, 2-MBI and 2-CBI were not directly compared as corrosion inhibitors for mild steel in $\mathrm{HCl}$, which would help us to better understand the effects of the substituents on the molecular structure. In this paper, the effects of BI, 2-CBI and 2-MBI on the mild-steel corrosion in a $\mathrm{HCl}$ solution $\left(1 \mathrm{~mol} \mathrm{~L}^{-1}\right)$ were studied; since the last one contains nitrogen and sulphur, it was expected to be a more efficient inhibitor than those containing only sulphur or nitrogen atoms. ${ }^{22,23}$ All the experiments were carried out using potentiodynamic polarization curves or electrochemical impedance spectroscopy (EIS). The standard adsorption free energy $\left(\Delta G^{0}\right.$ ads $)$ of the inhibitors and the apparent activation energy $\left(E_{\mathrm{a}}\right)$ of the mild-steel corrosion were discussed by monitoring the IE of different inhibitors as a function of the concentration and temperature.

\section{EXPERIMENTAL PART}

The chemical composition of the involved mild-steel samples is $\mathrm{C}=0.193 \%, \mathrm{Si}=0.272 \%, \mathrm{Mn}=0.436 \%$, $\mathrm{P}=0.033 \%$ and $\mathrm{S}=0.029 \%$. The cylindrical mild-steel specimens with a cross-section area of $0.5 \mathrm{~cm}^{2}$ and a height of $1.5 \mathrm{~cm}$ were welded with an insulated copper wire and sealed in PVC tubes with epoxy resin. After having been mechanically ground with 400, 600, 1000 and 1500 grit $\mathrm{SiC}$ abrasive papers, the epoxy-resinsealed mild-steel samples were washed with absolute ethanol and acetone and finally stored in a moisture-free desiccator before use. BI, 2-MBI and 2-CBI were purchased from Sigma-Aldrich (Shanghai) Trading Co., Ltd., without any further treatment before their use. $1 \mathrm{~mol} \mathrm{~L}^{-1} \mathrm{HCl}$ was prepared by dissolving reagent grade hydrochloric acid in bi-distilled water. $\mathrm{HCl}$ solutions with different concentrations of benzimidazole and its derivatives were used as the electrolyte.
A three-electrode cell containing a mild-steel specimen as the working electrode, a saturated calomel electrode (SCE) as the reference electrode, a platinum electrode as the counter electrode was used. All the electrochemical measurements were conducted with an AUTOLAB (AUT86742) instrument using $100 \mathrm{~mL}$ of the electrolyte in the stationary condition. Before every measurement, the working electrode was immersed in the corrosion cell for $30 \mathrm{~min}$ to achieve a stable state. The scanning scope of the polarization curves was $-250 \mathrm{mV}$ to $250 \mathrm{mV}$, relative to the open-circuit potential $\left(E_{\mathrm{oc}}\right)$ at $1 \mathrm{mV} \mathrm{s}^{-1}$. The scanning scope of EIS was 100 $\mathrm{KHz}$ to $10 \mathrm{mHz}$. All the experiments were measured three times to get the average values and the representative results are displayed in the figures below.

The morphology of the mild-steel surface before and after the immersion in $1 \mathrm{M} \mathrm{HCl}$ with or without different inhibitors was determined using a scanning electron microscope (JSM-6480, JEOL). After the immersion in the $\mathrm{HCl}$ solution, the specimens were ultrasonically cleaned and washed with absolute ethanol and acetone.

\section{RESULTS AND DISCUSSION}

\subsection{Effect of the inhibitor concentration}

We first researched the corrosion behaviours of mild steel in $1 \mathrm{~mol} \mathrm{~L}^{-1} \mathrm{HCl}$ with different concentrations of BI, 2-MBI and 2-CBI under room temperature (298 K). The results include polarization curves and EIS curves. The relative anodic and cathodic polarization curves are shown in Figure 1. Electrochemical parameters, such as the corrosion potential $\left(E_{\text {corr }}\right)$, cathodic and anodic Tafel slopes $\left(\beta_{\mathrm{c}}\right.$ and $\left.\beta_{\mathrm{a}}\right)$ as well as corrosion current density $\left(i_{\text {corr }}\right)$ were extrapolated from Figure 1 and displayed in Table 1. The degree of surface coverage $(\theta)$ and the percentage of IE $(\eta \%)$ were calculated using the following Equations (1) and (2):23,24

Table 1: Electrochemical parameters determined from the polarization curves in Figure 1

\begin{tabular}{|c|c|c|c|c|c|c|c|}
\hline \multirow[t]{2}{*}{ Inhibitor } & $\begin{array}{c}C \times 10^{3} \\
\left(\mathrm{~mol} \mathrm{~L} \mathrm{~L}^{-1}\right)\end{array}$ & $\begin{array}{c}-E_{\text {corr }} \times 10^{3} \\
(\mathrm{~V} / \mathrm{SCE})\end{array}$ & $\begin{array}{l}i_{\text {corr }} \times 10^{3} \\
\left(\mathrm{~A} \mathrm{~cm} \mathrm{~cm}^{-2}\right)\end{array}$ & $\begin{array}{c}\beta_{\mathrm{c}} \times 10^{3} \\
(\mathrm{~V} / \text { decade })\end{array}$ & $\begin{array}{c}\beta_{\mathrm{a}} \times 10^{3} \\
(\mathrm{~V} / \text { decade })\end{array}$ & $\theta$ & $\eta$ \\
\hline & Blank & $442 \pm 2.3$ & $661 \pm 3.1$ & $51 \pm 0.4$ & $135 \pm 2.3$ & I & I \\
\hline \multirow{5}{*}{ BI } & 0.43 & $456 \pm 1.9$ & $477 \pm 1.7$ & $49 \pm 0.7$ & $110 \pm 2.7$ & 0.2788 & $27.88 \%$ \\
\hline & 0.86 & $470 \pm 3.3$ & $433 \pm 2.4$ & $51 \pm 0.7$ & $107 \pm 0.7$ & 0.3457 & $34.57 \%$ \\
\hline & 1.29 & $464 \pm 2.7$ & $407 \pm 1.0$ & $49 \pm 0.5$ & $90 \pm 3.8$ & 0.3842 & $38.42 \%$ \\
\hline & 1.72 & $466 \pm 0.8$ & $392 \pm 0.7$ & $56 \pm 0.2$ & $109 \pm 4.3$ & 0.4070 & $40.70 \%$ \\
\hline & 2.15 & $468 \pm 1.2$ & $379 \pm 1.2$ & $50 \pm 1.1$ & $96 \pm 4.1$ & 0.4266 & $42.66 \%$ \\
\hline \multirow{5}{*}{ 2-MBI } & 0.31 & $476 \pm 3.3$ & $377 \pm 0.9$ & $47 \pm 2.5$ & $101 \pm 1.0$ & 0.4295 & $42.95 \%$ \\
\hline & 0.62 & $475 \pm 0.5$ & $346 \pm 1.1$ & $49 \pm 1.6$ & $104 \pm 0.4$ & 0.4770 & $47.70 \%$ \\
\hline & 0.93 & $480 \pm 0.9$ & $314 \pm 0.8$ & $46 \pm 0.9$ & $96 \pm 1.2$ & 0.5252 & $52.52 \%$ \\
\hline & 1.24 & $481 \pm 1.7$ & $298 \pm 0.3$ & $58 \pm 3.7$ & $128 \pm 0.7$ & 0.5492 & $54.92 \%$ \\
\hline & 1.55 & $477 \pm 2.3$ & $338 \pm 0.5$ & $49 \pm 4.3$ & $103 \pm 0.4$ & 0.4889 & $48.89 \%$ \\
\hline \multirow{5}{*}{ 2-CBI } & 0.31 & $444 \pm 1.3$ & $141 \pm 1.8$ & $69 \pm 2.1$ & $123 \pm 1.6$ & 0.7871 & $78.71 \%$ \\
\hline & 0.61 & $449 \pm 0.7$ & $126 \pm 5.1$ & $66 \pm 1.4$ & $140 \pm 4.1$ & 0.8088 & $80.88 \%$ \\
\hline & 0.91 & $458 \pm 1.1$ & $70 \pm 4.4$ & $66 \pm 1.1$ & $137 \pm 2.5$ & 0.8948 & $89.48 \%$ \\
\hline & 1.22 & $460 \pm 1.4$ & $60 \pm 2.7$ & $52 \pm 2.6$ & $124 \pm 3.2$ & 0.9089 & $90.89 \%$ \\
\hline & 1.52 & $467 \pm 0.8$ & $38 \pm 1.4$ & $57 \pm 3.1$ & $112 \pm 5.4$ & 0.9431 & $94.31 \%$ \\
\hline
\end{tabular}




$$
\begin{gathered}
\theta=\frac{i_{\text {corr }}^{0}-i_{\text {corr }}}{i_{\text {corr }}^{0}} \\
\eta / \%=\theta \times 100 \%
\end{gathered}
$$

where $i^{0}$ corr is the corrosion current density of mild steel in $1 \mathrm{M} \mathrm{HCl}$ without inhibitors.

As we can see from Figure 1 and Table 1, the corrosion current density $i_{\text {corr }}$ of mild steel in the $\mathrm{HCl}$ solutions containing $\mathrm{BI}$ or its derivatives with different concentrations are lower than that in the $\mathrm{HCl}$ solutions without additives (blank). For BI and 2-CBI, the $i_{\text {corr }}$ of mild steel in $1 \mathrm{M} \mathrm{HCl}$ decreases at all the inhibitor concentrations while for 2-MBI, the $i_{\text {corr }}$ shows the minimum value at $1.24 \times 10^{-3} \mathrm{~mol} \mathrm{~L}^{-1}$, indicating desorption at higher con-
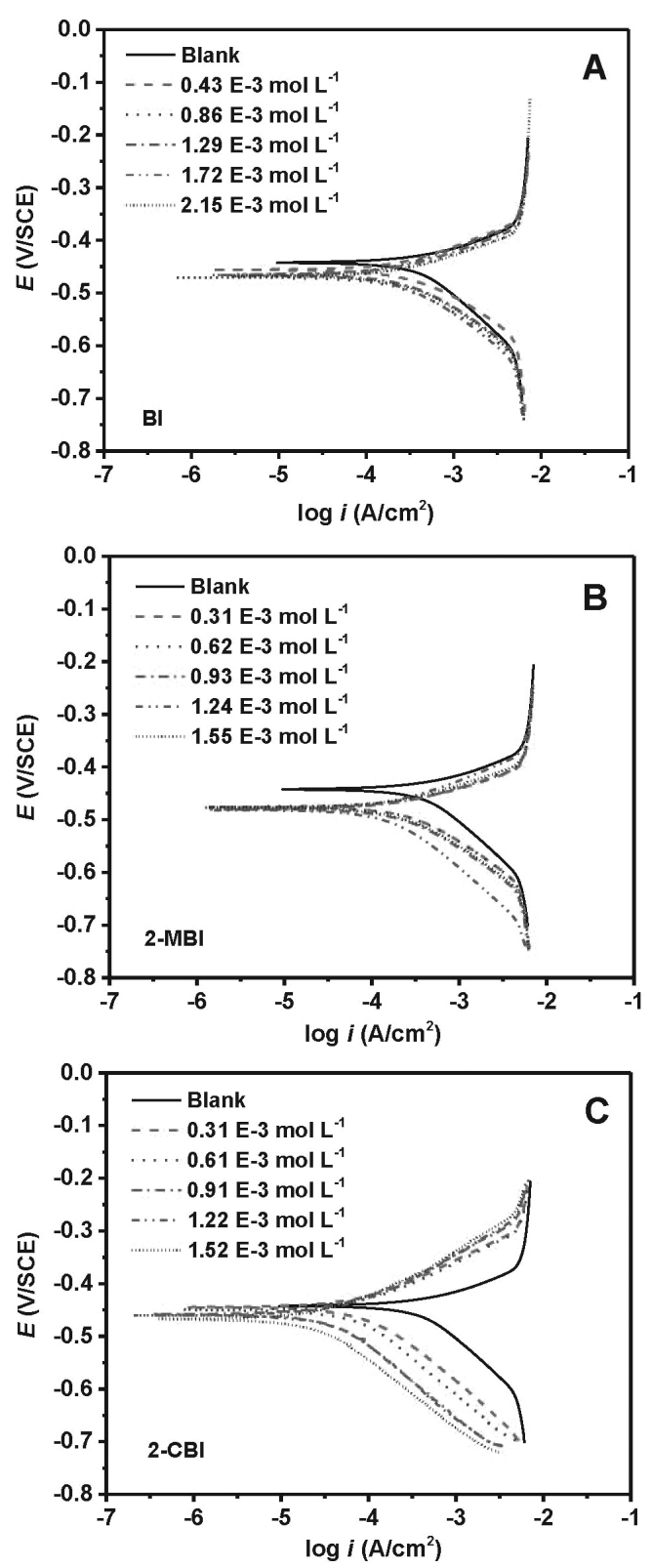

Figure 1: Polarization curves of mild steel in $1 \mathrm{M} \mathrm{HCl}$ with different inhibitors at $398 \mathrm{~K}$ : a) benzimidazole (BI), b) 2-methylthiobenzimidazole (2-MBI) and c) 2-chloromethylbenzimidazole (2-CBI) centrations. In the report published by J. Aljourani and co-workers, the IE of $\mathrm{BI}$ for mild steel in $1 \mathrm{M} \mathrm{HCl}$ changed from 36.6 to $52.2 \%$ with a concentration range from $0.43 \times 10^{-3} \mathrm{~mol} \mathrm{~L}^{-1}$ to $2.15 \mathrm{~mol} \mathrm{~L}^{-1}$ and the results of our work are basically the same. ${ }^{11}$ The IE of 2-methylbenzimidazole from reference ${ }^{11}$ and the IE of 2-MBI found with our research are both lower than the IE of 2-mercaptobenzimidazole from reference. ${ }^{11}$ Nevertheless, the IE of 2-CBI is the highest among the compounds from reference ${ }^{11}$ and our research, e.g., when $2-\mathrm{CBI}$ in the $\mathrm{HCl}$ solution is $1.52 \mathrm{~mol} \mathrm{~L}^{-1}$, the IE is $94.31 \%$.

In addition, the results of our work are also consistent with the report published by K. F. Khaled, ${ }^{20}$ in which 2-CBI also has a higher IE than 2-MBI for iron in $1 \mathrm{M}$
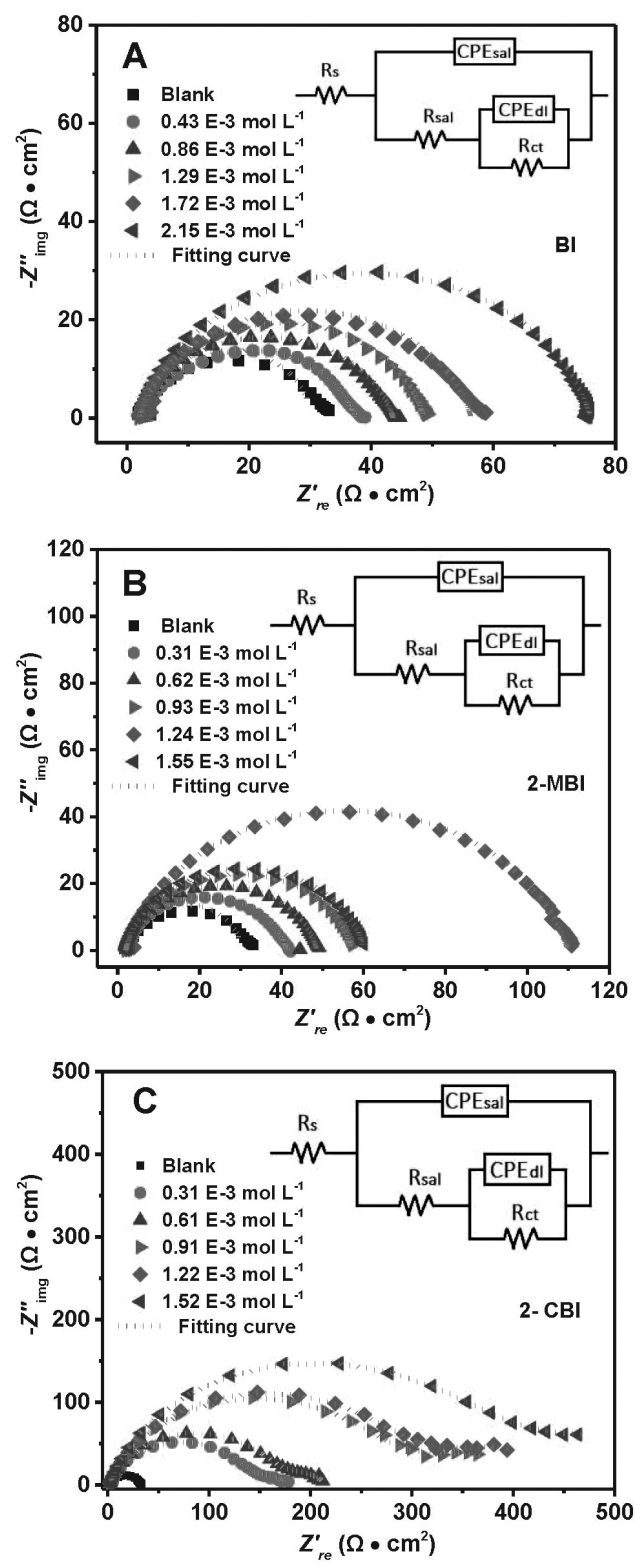

Figure 2: Nyquist plots of mild steel in $1 \mathrm{M} \mathrm{HCl}$ with different concentrations of: a) benzimidazole (BI), b) 2-methylthiobenzimidazole (2-MBI) and c) 2-chloromethylbenzimidazole (2-CBI) at $303 \mathrm{~K}$ 
$\mathrm{HNO}_{3}$ at identical concentrations; the reasons for this were found to be a higher HOMO energy and a larger $\Delta N$ of 2-CBI. We believe that these reasons can also be used to interpret the higher IE of 2-CBI compared to 2-MBI for mild steel, found in our work. In addition, the difference between 2-CBI and 2-MBI can probably be attributed to the effects of the substituted group on the electron-cloud distribution of BI and the conformation of the inhibitor molecules. Hence, we can draw a conclusion that, just like BI, both BI derivatives can be used as inhibitors for mild steel in an $\mathrm{HCl}$ solution. The IE of the three inhibitors increases in the order of $\mathrm{BI}<2$-MBI $<$ 2-CBI.

In order to verify the phenomena presented in Figure 1, we conducted EIS measurements of the mild steel in $1 \mathrm{M} \mathrm{HCl}$ with the three inhibitors. The electrical equivalent circuit inserted in Figure $2 \mathrm{~A}, \mathrm{~B}$ and $\mathrm{C}$ was used to fit the EIS data and the results are shown in Figure 2 and Table 2. They reveal that the Nyquist plots contain a depressed semi-circle, with the centre below the real $\mathrm{X}$ axis, which means that the corrosion is mainly a charge-transfer process. ${ }^{25}$ Also, the total resistance, $R_{\text {tot }}$, which represents the corrosion-protection ability of the layers, as well the percentage of inhibition efficiency $(\eta \%)$ were evaluated with the following Equations (3) and (4): ${ }^{17}$

$$
\begin{gathered}
R_{\mathrm{tot}}=R_{\mathrm{sal}}+R_{\mathrm{ct}} \\
\eta / \%=\frac{R_{\mathrm{tot}}-R_{0}}{R_{\mathrm{tot}}} \times 100
\end{gathered}
$$

where $R_{\mathrm{sal}}$ is the resistance of electrons or ions through the inhibitor layer, $R_{\mathrm{ct}}$ is the charge-transfer resistance, and $R_{0}$ is the charge-transfer resistance without the inhibitor.

For BI and 2-CBI, the radius of the semi-circle and $R_{\text {tot }}$ increase with the inhibitor concentration. On the other hand, for 2-MBI, the radius of the semi-circle and $R_{\text {tot }}$ increase with the concentration increase to $1.24 \times 10^{-3}$ mol $\mathrm{L}^{-1}$, and then they decrease when the concentration is $1.55 \times 10^{-3} \mathrm{~mol} \mathrm{~L}^{-1}$, which indicates the desorption of $2-\mathrm{MBI}$ at a higher concentration. For $\mathrm{BI}$ and $2-\mathrm{MBI}, R_{\mathrm{tot}}$ is mostly derived from $R_{\mathrm{ct}}$, while for 2-CBI, $R_{\mathrm{tot}}$ is much bigger than that of the other two, and $R_{\text {sal }}$ is comparable to $R_{\mathrm{ct}}$. This phenomenon may be interpreted as the BI and 2-MBI layer being able to change the structure of the double electric layer, but with a lower resistance. However, not only $R_{\mathrm{ct}}$, but also $R_{\text {sal }}$ increased sharply when 2-CBI was used as the inhibitor. This means that in addition to increasing the resistance of the double electric layer, 2-CBI can also form a dense molecular layer with a higher resistance. Whatever, the IE values we calculated from the EIS curves (Table 2) are the same, with the tendency of the anodic and cathodic polarization curves shown in Figure 1 and Table 1.

\subsection{Morphological characterization}

The surface morphologies of the mild-steel specimens immersed in $1 \mathrm{M} \mathrm{HCl}$ for 7 days with or without different inhibitors are presented in Figure 3. Figure 3B reveals that the surface morphology of the mild steel immersed in the $\mathrm{HCl}$ solution without an inhibitor is rough and porous, which means that the specimen was seriously corroded by the HCL solution. Figures 3C-D show the surface morphologies of the mild steel immersed in the $\mathrm{HCl}$ solution with BI, 2-MBI and 2-CBI, respectively. In contrast, the surfaces of these mild-steel specimens were protected by the three compounds, which proves that they can be used as inhibitors for mild steel in $\mathrm{HCl}$. It should be emphasized that the surface morphology of the specimen with 2-CBI as the inhibitor is nearly the same as the freshly polished mild steel (Figure 3A). Moreover, the smoothness of the mild-steel surface increases in the order of $\mathrm{BI}<2$-MBI $<$ 2-CBI, which also supports the results obtained from the polarization curves and EIS.

\begin{tabular}{|c|c|c|c|c|c|c|}
\hline Inhibitor & $C \times 10^{3}\left(\mathrm{~mol} \mathrm{~L}^{-1}\right)$ & $R_{\mathrm{ct}}\left(\Omega \mathrm{cm}^{2}\right)$ & $R_{\text {sal }}\left(\Omega \mathrm{cm}^{2}\right)$ & $R_{\mathrm{tot}}\left(\Omega \mathrm{cm}^{2}\right)$ & $\eta$ & $\theta$ \\
\hline \multirow{6}{*}{ BI } & Blank & $27.5 \pm 1.7$ & $0.08 \pm 0.02$ & 27.5 & 1 & 1 \\
\hline & 0.43 & $34.5 \pm 0.8$ & $0.92 \pm 0.06$ & 35.4 & $22.33 \%$ & 0.2233 \\
\hline & 0.86 & $40.8 \pm 1.8$ & $1.43 \pm 0.11$ & 42.2 & $34.86 \%$ & 0.3486 \\
\hline & 1.29 & $45.8 \pm 3.2$ & $1.22 \pm 0.15$ & 47.0 & $41.49 \%$ & 0.4149 \\
\hline & 1.72 & $52.1 \pm 2.2$ & $4.14 \pm 0.21$ & 56.2 & $51.08 \%$ & 0.5108 \\
\hline & 2.15 & $74.0 \pm 1.9$ & $0.35 \pm 0.12$ & 74.4 & $63.00 \%$ & 0.6300 \\
\hline \multirow{5}{*}{ 2-MBI } & 0.31 & $38.0 \pm 1.5$ & $1.78 \pm 0.49$ & 39.8 & $30.84 \%$ & 0.3084 \\
\hline & 0.62 & $45.8 \pm 2.2$ & $1.18 \pm 0.37$ & 47.0 & $41.44 \%$ & 0.4144 \\
\hline & 0.93 & $53.7 \pm 4.3$ & $1.81 \pm 0.61$ & 55.5 & $50.44 \%$ & 0.5044 \\
\hline & 1.24 & $89.8 \pm 3.6$ & $2.19 \pm 0.83$ & 92.0 & $70.09 \%$ & 0.7099 \\
\hline & 1.55 & $58.1 \pm 6.8$ & $1.91 \pm 0.66$ & 60.0 & $54.16 \%$ & 0.5416 \\
\hline \multirow{5}{*}{ 2-CBI } & 0.31 & $139.7 \pm 11.8$ & $35.1 \pm 7.7$ & 174.8 & $84.26 \%$ & 0.8426 \\
\hline & 0.61 & $164.8 \pm 17.7$ & $49.5 \pm 7.1$ & 214.3 & $87.16 \%$ & 0.8716 \\
\hline & 0.91 & $281.8 \pm 16.5$ & $139.8 \pm 5.3$ & 421.6 & $93.47 \%$ & 0.9347 \\
\hline & 1.22 & $290.3 \pm 21.1$ & $207.6 \pm 10.8$ & 497.9 & $94.47 \%$ & 0.9447 \\
\hline & 1.52 & $362.9 \pm 27.5$ & $307.5 \pm 16.5$ & 670.4 & $95.90 \%$ & 0.9590 \\
\hline
\end{tabular}

Table 2: Electrochemical parameters determined from the Nyquist plots in Figure 2 

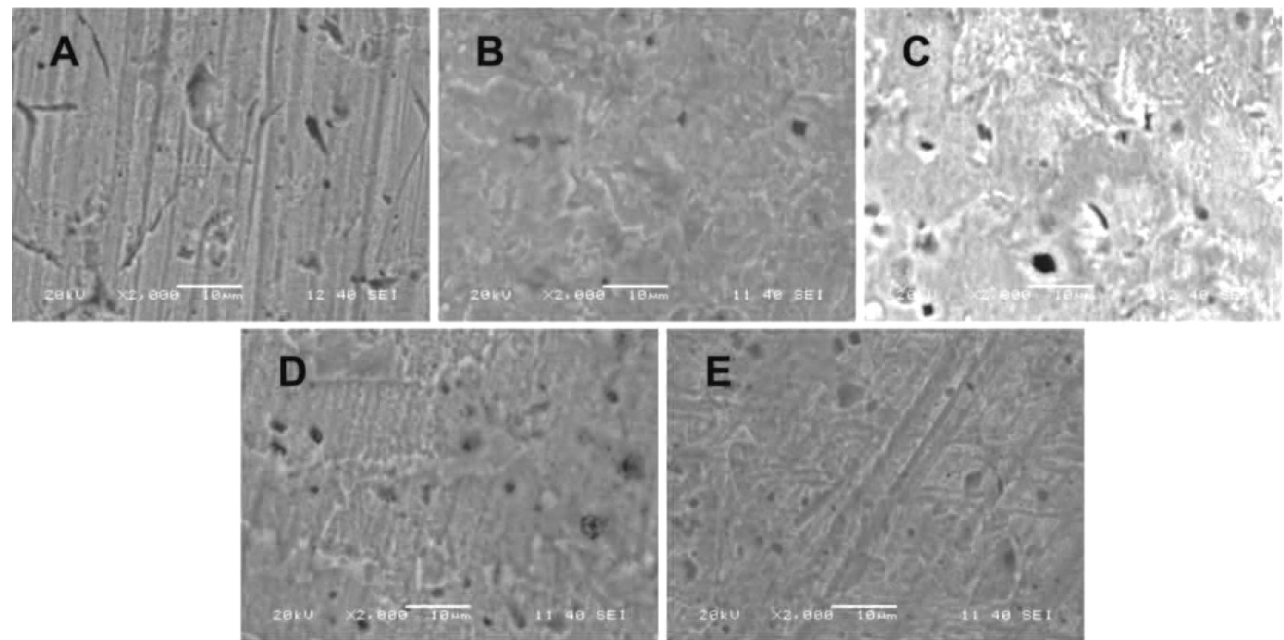

Figure 3: a) Morphology of the freshly polished mild-steel surface after the immersion in the $1 \mathrm{M} \mathrm{HCl}$ solution for $7 \mathrm{~d}$ without the inhibitor, b) with $0.43 \times 10^{-3} \mathrm{~mol} \mathrm{~L}^{-1}$ benzimidazole (BI), c) with $1.24 \times 10^{-3} \mathrm{~mol} \mathrm{~L}^{-1}$ 2-methylthiobenzimidazole (2-MBI), d) with $1.22 \times 10^{-3}$ mol $\mathrm{L}^{-1}$ 2-chloromethylbenzimidazole (2-CBI) (E)
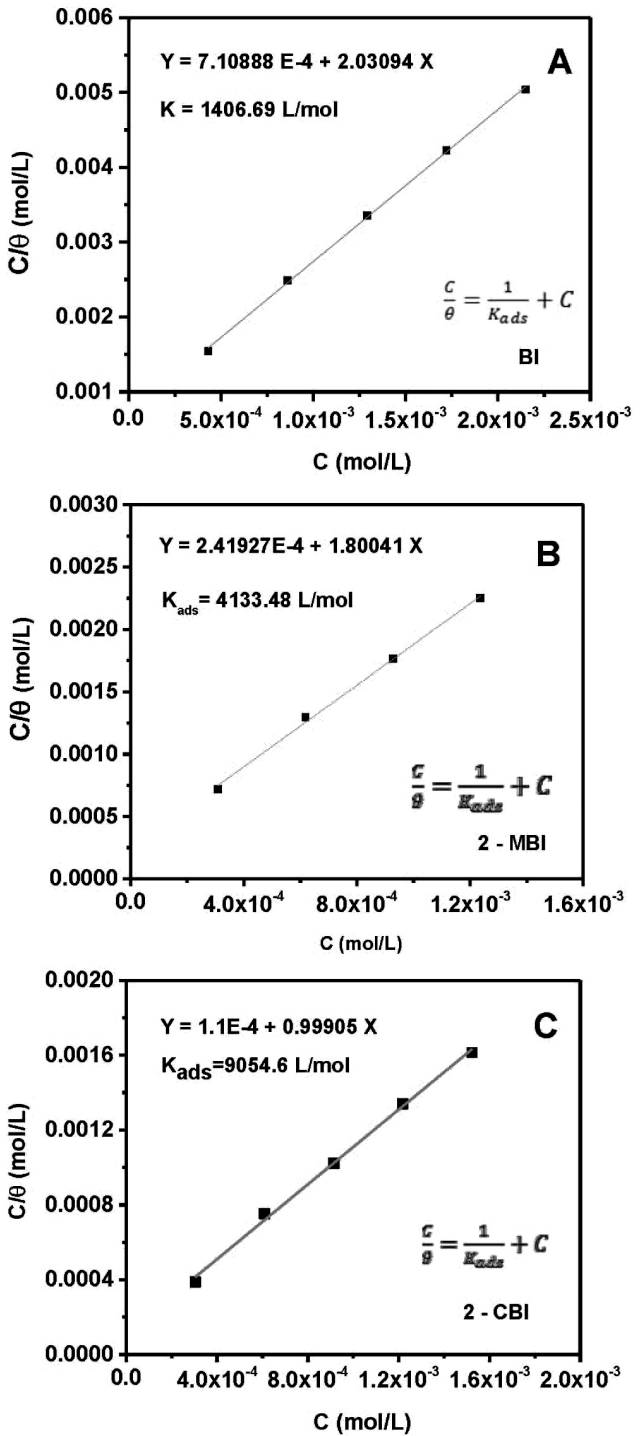

Figure 4: Adsorption-isotherm fitting curves of the three inhibitors on the mild steel in $1 \mathrm{M} \mathrm{HCl}$ at $398 \mathrm{~K}$ : a) benzimidazole (BI), b) 2-methylthiobenzimidazole (2-MBI), c) 2-chloromethylbenzimidazole (2-CBI)

\subsection{Adsorption isotherms}

Furthermore, the adsorption isotherms of BI and its derivatives used on the mild-steel surface in the $\mathrm{HCl}$ solution were investigated in this research, and the results are shown in Figure 4 and Table 3. Different adsorption models mainly include Langmuir, ${ }^{26}$ Brunauer-EmmettTeller (BET), ${ }^{27}$ Temkin, ${ }^{28}$ Multisite Langmuir, ${ }^{29}$ FloryHuggins ${ }^{30}$ and Frumkin. ${ }^{31}$ It was found that the adsorption of all three inhibitors onto the mild steel in the $\mathrm{HCl}$ solution can be effectively described with the Langmuir adsorption isotherm, in which $C / \theta$ can be represented as: $^{32}$

$$
\frac{C}{\theta}=\frac{1}{K_{\text {ads }}}+C
$$

Where $K_{\text {ads }}$ is the adsorption equilibrium constant; the $K_{\text {ads }}$ of BI, 2-MBI and 2-CBI adsorbed onto the mildsteel surface was calculated as $(1406.69,4133.48$ and 9054.6) $\mathrm{L} \mathrm{mol}^{-1}$, respectively.

Table 3: Adsorption thermodynamic parameters of different inhibitors on the mild steel in $1 \mathrm{M} \mathrm{HCl}$ and the subsequent apparent activation energy of mild steel

\begin{tabular}{|c|c|c|c|}
\hline & $\begin{array}{c}K_{\text {ads }} \\
\mathrm{L} / \mathrm{mol}\end{array}$ & $\begin{array}{c}\Delta G_{\text {ads }}^{0} \\
\mathrm{KJ} / \mathrm{mol}\end{array}$ & $\begin{array}{c}E_{\mathrm{a}} \\
\mathrm{KJ} / \mathrm{mol}\end{array}$ \\
\hline Blank & - & - & 33.74 \\
\hline BI & $1.41 \times 10^{3}$ & -27.91 & 42.00 \\
\hline 2-MBI & $4.13 \times 10^{3}$ & -30.58 & 48.28 \\
\hline 2-CBI & $9.05 \times 10^{3}$ & -32.52 & 67.93 \\
\hline
\end{tabular}

Based on the $K_{\text {ads }}$ values for different inhibitors, the standard free energy of adsorption $\Delta G_{\text {ads }}^{0}$ can be calculated with the following Equation (6): $:^{33-35}$

$$
\Delta G_{\text {ads }}^{0}=-R T \ln \left(55.5 K_{\text {ads }}\right)
$$

where $R$ is the gas constant and $T$ is the absolute temperature. The value of 55.5 is the concentration of water in the solution in mol L-1. The $\Delta G^{0}$ ads values of the 
three inhibitors are presented in Table 3. A larger $K_{\text {ads }}$ is preferable for the inhibitors adsorbed onto the mild-steel surface, and the negative $\Delta G^{0}$ ads means that the adsorption is spontaneous. ${ }^{36-38}$ Table 3 reveals that the $K_{\text {ads }}$ increased in the order of $\mathrm{BI}<2-\mathrm{MBI}<2-\mathrm{CBI}$, and the respective $\Delta G^{0}$ ads values are $(-27.91,-30.58$ and -32.52) $\mathrm{kJ} \mathrm{mol}^{-1}$. The interaction between the inhibitors and the mild-steel surface is reflected by the absolute value of $\Delta G^{0}$ ads: if it is not more than $20 \mathrm{~kJ} \mathrm{~mol}^{-1}$, the interaction is an electrostatic force (physisorption); if it is not less than $40 \mathrm{~kJ} \mathrm{~mol}^{-1}$, the interaction involves sharing and a transfer of electrons from the inhibitors to the metal surface (chemisorption). ${ }^{39}$ In this research, all the absolute values of $\Delta G^{0}$ ads are around $30 \mathrm{~kJ} \mathrm{~mol}^{-1}$, indicating that the interaction between the three inhibitors and mild steel may be a mix of physisorption and chemisorption.

\subsection{Effects of the temperature}

The effects of the temperature on the corrosion current density of mild steel can be used to determine the apparent activation energy $\left(E_{\mathrm{a}}\right)$ of mild-steel corrosion in the $\mathrm{HCl}$ solution with or without inhibitors. The effects of the temperature on the polarization curves are presented in Figure 5; the $i_{\text {corr }}$ values of the mild steel in $1 \mathrm{M} \mathrm{HCl}$ with different inhibitors (fixed concentrations) were extrapolated from these polarization curves, and the results are recorded in Table 4. We used the following Equation (7):40

$$
\ln i_{\text {corr }}=\ln A-\frac{E_{\mathrm{a}}}{R T}
$$

Where $A$ is the Arrhenius pre-exponential constant. The relative electrochemical parameters are listed in Table 4, and the fitted straight lines of $\ln i_{\text {corr }}$ as a function of the reciprocal of temperature are displayed in
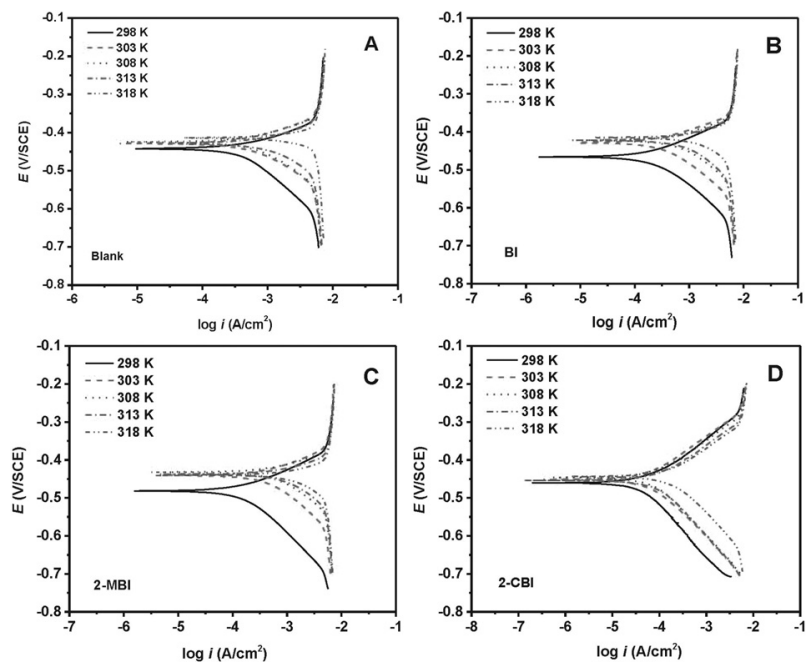

Figure 5: Polarization curves of mild steel in $1 \mathrm{M} \mathrm{HCl}$ with or without inhibitors at different temperatures: a) blank, b) benzimidazole (BI), c) 2-methylthiobenzimidazole (2-MBI), d) 2-chloromethylbenzimidazole (2-CBI)
Figure 6. Based on the slopes of the straight lines $\left(-E_{\mathrm{a}} / \mathrm{RT}\right)$, the apparent activation energy of the mild steel in $\mathrm{HCl}$ with different inhibitors is recorded in Table 3.

Table 4: Electrochemical parameters extrapolated from the polarization curves in Figure 5

\begin{tabular}{|c|c|c|c|c|c|}
\hline Inhibitor & $T(\mathrm{~K})$ & $\begin{array}{c}-E_{\text {corr }} \times 10^{3} \\
(\mathrm{~V} / \mathrm{SCE})\end{array}$ & $\begin{array}{l}i_{\text {corr }} \times 10^{6} \\
\left(\mathrm{~A} \mathrm{~cm}^{-2}\right)\end{array}$ & $\theta$ & $\eta$ \\
\hline \multirow{5}{*}{ Blank } & $298 K$ & $442 \pm 2.3$ & $661 \pm 3.1$ & - & - \\
\hline & $303 \mathrm{~K}$ & $428 \pm 0.5$ & $825 \pm 2.9$ & - & - \\
\hline & $308 \mathrm{~K}$ & $424 \pm 0.6$ & $1010 \pm 2.2$ & - & - \\
\hline & $313 \mathrm{~K}$ & $428 \pm 1.0$ & $1290 \pm 6.8$ & - & - \\
\hline & $318 \mathrm{~K}$ & $414 \pm 0.3$ & $1541 \pm 9.7$ & - & - \\
\hline \multirow{5}{*}{ BI } & $298 K$ & $466 \pm 0.8$ & $392 \pm 0.7$ & 0.4070 & $40.70 \%$ \\
\hline & $303 \mathrm{~K}$ & $428 \pm 2.3$ & $521 \pm 3.1$ & 0.3686 & $36.86 \%$ \\
\hline & $308 \mathrm{~K}$ & $422 \pm 1.8$ & $663 \pm 2.5$ & 0.3434 & $34.34 \%$ \\
\hline & $313 \mathrm{~K}$ & $422 \pm 1.6$ & $895 \pm 5.3$ & 0.3060 & $30.60 \%$ \\
\hline & $318 \mathrm{~K}$ & $413 \pm 0.9$ & $1130 \pm 5.8$ & 0.2668 & $26.68 \%$ \\
\hline \multirow{5}{*}{ 2-MBI } & $298 K$ & $481 \pm 1.7$ & $298 \pm 0.3$ & 0.5492 & $54.92 \%$ \\
\hline & $303 \mathrm{~K}$ & $440 \pm 2.7$ & $409 \pm 7.6$ & 0.5041 & $50.41 \%$ \\
\hline & $308 \mathrm{~K}$ & $432 \pm 1.5$ & $545 \pm 1.8$ & 0.4629 & $46.29 \%$ \\
\hline & $313 \mathrm{~K}$ & $437 \pm 2.9$ & $769 \pm 8.8$ & 0.4036 & $40.36 \%$ \\
\hline & $318 \mathrm{~K}$ & $439 \pm 2.5$ & $1006 \pm 6.6$ & 0.3473 & $34.73 \%$ \\
\hline \multirow{5}{*}{ 2-CBI } & $298 K$ & $460 \pm 1.4$ & $60 \pm 2.7$ & 0.9089 & $90.89 \%$ \\
\hline & $303 \mathrm{~K}$ & $451 \pm 3.4$ & $936 \pm 2.9$ & 0.8878 & $88.78 \%$ \\
\hline & $308 \mathrm{~K}$ & $446 \pm 6.7$ & $141 \pm 6.1$ & 0.8608 & $86.08 \%$ \\
\hline & $313 \mathrm{~K}$ & $454 \pm 3.7$ & $228 \pm 4.7$ & 0.8229 & $82.29 \%$ \\
\hline & $318 \mathrm{~K}$ & $443 \pm 3.2$ & $330 \pm 10.5$ & 0.7861 & $78.61 \%$ \\
\hline
\end{tabular}

It is not surprising that with various inhibitors, $E_{\mathrm{a}}$ of the mild-steel corrosion in $1 \mathrm{M} \mathrm{HCl}$ increased in the order of BI $\left(42.00 \mathrm{~kJ} \mathrm{~mol}^{-1}\right)<2$-MBI $\left(48.28 \mathrm{~kJ} \mathrm{~mol}^{-1}\right)<$ 2-CBI $\left(67.93 \mathrm{~kJ} \mathrm{~mol}^{-1}\right)$; all its values are higher than the one obtained without the inhibitor $\left(33.74 \mathrm{~kJ} \mathrm{~mol}^{-1}\right)$. Thus, this tendency is consistent with that of IE.

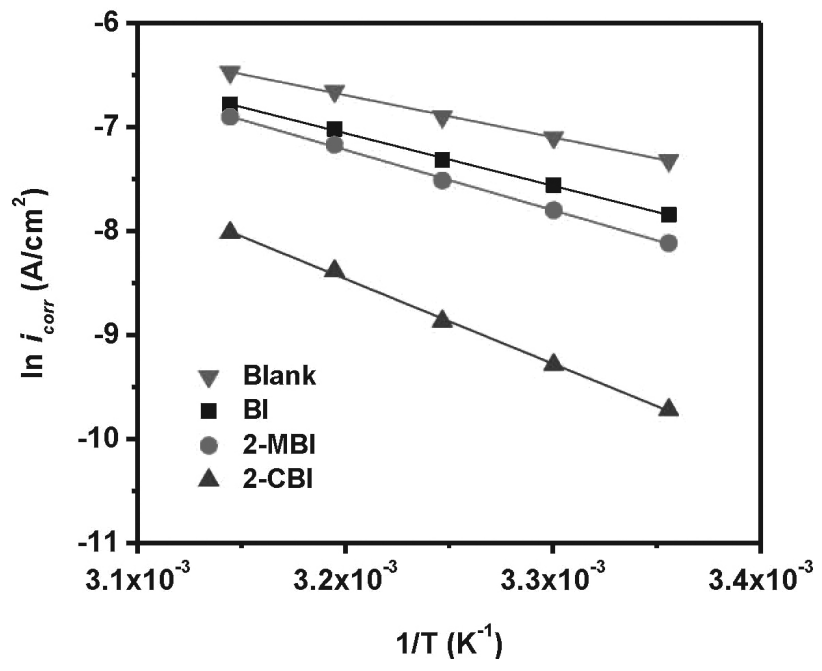

Figure 6: $\ln i_{\text {corr }}$ as a function of $1 / T$ for mild steel in $1 \mathrm{M} \mathrm{HCl}$ in the absence or presence of $0.43 \times 10^{-3} \mathrm{~mol} \mathrm{~L}^{-1}$ benzimidazole (BI), $1.24 \times 10^{-3} \mathrm{~mol} \mathrm{\textrm {L } ^ { - 1 }}$ 2-methylthiobenzimidazole (2-MBI) and $1.22 \times 10^{-3} \mathrm{~mol} \mathrm{~L}^{-1}$ 2-chloromethylbenzimidazole (2-CBI) 


\section{CONCLUSIONS}

So far, we have come to the following conclusions by measuring electrochemical behaviours of mild steel in $1 \mathrm{M} \mathrm{HCl}$ with or without benzimidazole and its derivatives:

1. Benzimidazole (BI), 2-methylthiobenzimidazole (2-MBI) and 2-chloromethylbenzimidazole (2-CBI) can be used as corrosion inhibitors for mild steel in 1 $\mathrm{M} \mathrm{HCl}$. For BI and 2-CBI, the inhibition efficiency (IE) increased with the increasing concentration. However, the IE of 2-MBI decreased when the concentration reached $1.24 \times 10^{-3} \mathrm{~mol} \mathrm{~L}^{-1}$ due to the desorption process. Under the same condition, IE improved the most for $\mathrm{BI}$, followed by $2-\mathrm{MBI}$ and 2-CBI.

2. In this research, the adsorption of $\mathrm{BI}, 2-\mathrm{MBI}$ and 2-CBI onto the mild steel in $1 \mathrm{M} \mathrm{HCl}$ was found to obey the Langmuir adsorption isotherm. The adsorption equilibrium constant $\left(K_{\mathrm{ads}}\right)$ of the inhibitors adsorbed onto the mild steel in $1 \mathrm{M} \mathrm{HCl}$ also improved in the same order as IE.

3. With an increase in the temperature, the corrosion current density increased as well. The values for the apparent activation energy $\left(E_{\mathrm{a}}\right)$ of mild-steel corrosion in the $\mathrm{HCl}$ solution with the inhibitors are all higher than the one obtained without the inhibitor. Moreover, the variation in $E_{\mathrm{a}}$ is in accordance with the IE values for the three inhibitors.

\section{Acknowledgments}

The authors appreciate the financial support from the Undergraduate Innovation Programs of the Jiangsu University of Science and Technology (201710289099X), the Natural Science Foundation of the Higher Education Institutions of the Jiangsu Province (China) (17KJD430002), the Doctoral Scientific Research Foundation of the Jiangsu University of Science and Technology (1062931603) and the Priority Academic Program Development of the Jiangsu Higher Education Institutions.

\section{REFERENCES}

C. B. Zheng, X. Chen, ZrMoN films on 304 stainless steel as bipolar plates for PEMFCs using physical-vapor-deposition (PVD) technology, Mater. Tehnol., 51 (2017) 4, 699-705, doi:10.17222/mit.2016. 316

${ }^{2}$ X. Y. Lu, X. G. Feng, Y. Zuo, P. Zhang, C. B. Zheng, Improvement of protection performance of $\mathrm{Mg}$-rich epoxy coating on AZ91D magnesium alloy by DC anodic oxidation, Progress in Organic Coatings, 104 (2017), 188-198, doi:10.1016/j.porgcoat.2016.11.001

Z. B. Wang, H. X. Hu, Y. G. Zheng, W. Ke, Y. X. Qiao, Comparison of the corrosion behavior of pure titanium and its alloys in fluoride-containing sulfuric, Corrosion Science, 103 (2016), 50-65, doi:10.1016/j.corsci.2015.11.003

${ }^{4}$ G. Trabanelli, 1991 Whitney Award Lecture: Inhibitors - An Old Remedy for a New Challenge, Corrosion, 47 (1991) 6, 410-419, doi:10.5006/1.3585271
${ }^{5}$ Y. Qiang, S. Zhang, L. Guo, X. Zheng, B. Xiang, S. Chen, Experimental and theoretical studies of four allyl imidazolium-based ionic liquids as green inhibitors for copper corrosion in sulfuric acid, Corrosion Science, 119 (2017), 68-78, doi:10.1016/j.corsci.2017. 02.021

${ }^{6}$ C. B. Zheng, L. Cai, Z. J. Tang, X. L. Shen, The inhibition effect of the molybdate on hydrogen permeation of 2205 duplex stainless steel, Surface and Coatings Technology, 287 (2016), 153-159, doi:10.1016/j.surfcoat.2015.12.077

${ }^{7}$ M. Hosseini, S. F. L. Mertens, M. Ghorbani, M. R. Arshadi, Asymmetrical Schiff bases as inhibitors of mild steel corrosion in sulphuric acid media, Materials Chemistry and Physics, 78 (2003) 3, 800-808, doi:10.1016/S0254-0584(02)00390-5

${ }^{8}$ M. Hosseini, S. F. L. Mertens, M. R. Arshadi, Synergism and antagonism in mild steel corrosion inhibition by sodium dodecylbenzenesulphonate and hexamethylenetetramine, Corrosion Science, 45 (2003) 7, 1473-1489, doi:10.1016/S0010-938X(02)00246-9

${ }^{9}$ K. C. Emregül, M. Hayvali, Studies on the effect of vanillin and protocatechualdehyde on the corrosion of steel in hydrochloric acid, Materials Chemistry and Physics, 83 (2004) 2-3, 209-216, doi:10.1016/j.matchemphys.2003.08.030

${ }^{10}$ M. Lebrini, M. Lagrenée, H. Vezin, L. Gengembre, F. Bentiss, Electrochemical and quantum chemical studies of new thiadiazole derivatives adsorption on mild steel in normal hydrochloric acid medium, Corrosion Science, 47 (2005) 2, 485-505, doi:10.1016/ j.corsci.2004.06.001

${ }^{11}$ J. Aljourani, K. Raeissi, M. A. Golozar, Benzimidazole and its derivatives as corrosion inhibitors for mild steel in $1 \mathrm{M} \mathrm{HCl}$ solution, Corrosion Science, 51 (2009) 8, 1836-1843, doi:10.1016/j.corsci. 2009.05.011

${ }^{12}$ M. Mahdavian, S. Ashhari, Corrosion inhibition performance of 2-mercaptobenzimidazole and 2-mercaptobenzoxazole compounds for protection of mild steel in hydrochloric acid solution, Electrochimica Acta, 55 (2010) 5, 1720-1724, doi:10.1016/j.electacta. 2009.10.055

${ }^{13}$ S. Sun, Y. Geng, L. Tian, S. Chen, Y. Yan, S. Hu, Density functional theory study of imidazole, benzimidazole and 2-mercaptobenzimidazole adsorption onto clean $\mathrm{Cu}(111)$ surface, Corrosion Science, 63 (2012), 140-147, doi:10.1016/j.corsci.2012.05.024

${ }^{14}$ M. E. Olvera-Martinez, J. Mendoza-Flores, F. J. Rodriguez-Gomez, M. E. Palomar-Pardave, J. Genesca, Effects of turbulent flow on the corrosion inhibition properties of 2-mercaptobenzimidazole, Materials and Corrosion, 64 (2013) 6, 522-529, doi:10.1002/maco. 201106323

${ }^{15}$ M. Yadav, D. Behera, S. Kumar, R. R. Sinha, Experimental and quantum chemical studies on the corrosion inhibition performance of benzimidazole derivatives for mild steel in $\mathrm{HCl}$, Industrial \& Engineering Chemistry Research, 52 (2013) 19, 6318-6328. doi:10.1021/ie400099q

${ }^{16}$ P. Morales-Gil, M. S. Walczak, C. Ruiz Camargo, R. A. Cottis, J. M. Romero, R. Lindsay, Corrosion inhibition of carbon-steel with 2-mercaptobenzimidazole in hydrochloric acid, Corrosion Science, 101 (2015), 47-55, doi:10.1016/j.corsci.2015.08.032

${ }^{17} \mathrm{G}$. Žerjav, I. Milošev, Corrosion protection of brasses and zinc in simulated urban rain. Part II. The combination of inhibitors benzotriazole and 2-mercaptobenzimidazole with stearic acid, Materials and Corrosion, 67 (2016) 1, 92-103, doi:10.1002/maco. 201508384

${ }^{18}$ K. F. Khaled, The inhibition of benzimidazole derivatives on corrosion of iron in $1 \mathrm{M} \mathrm{HCl}$ solutions, Electrochimica Acta, 48 (2003) 17, 2493-2503, doi:10.1016/S0013-4686(03)00291-3

${ }^{19}$ P. Morales-Gil, M. S. Walczak, R. A. Cottis, J. M. Romero, R. Lindsay, Corrosion inhibitor binding in an acidic medium: Interaction of 2-mercaptobenizmidazole with carbon-steel in hydrochloric acid, Corrosion Science, 85 (2014), 109-114, doi:10.1016/j.corsci. 2014.04.003

${ }^{20}$ K. F. Khaled, Experimental and computational investigations of corrosion and corrosion inhibition of iron in acid solutions, Journal of Applied Electrochemistry, 41 (2011) 3, 277-287, doi:10.1016/ j.apsusc.2007.01.075 


\section{Z. LI et al.: BENZIMIDAZOLE AND ITS DERIVATIVES AS CORROSION INHIBITORS FOR MILD STEEL ...}

${ }^{21}$ R. L. Camachomendoza, E. Gutiérrezmoreno, E. Guzmánpercástegui, E. Aquinotorres, J. Cruzborbolla, J. A. Rodríguezávila, J. G. Alvaradorodríguez, O. Olveraneria, P. Thangarasu, J. L. MedinaFranco, DFT and electrochemical studies: Structure-efficiency relationship on corrosion inhibition, J. Chem. Inf. Model., 267 (2015) 9, 6081-6085, doi:10.1021/acs.jcim.5b00385

${ }^{22}$ O. Benali, L. Larabi, M. Traisnel, L. Gengembre, Y. Harek, Electrochemical, theoretical and XPS studies of 2-mercapto-1-methylimidazole adsorption on carbon steel in $1 \mathrm{M} \mathrm{HClO}_{4}$, Applied Surface Science, 253 (2007) 14, 6130-6139, doi:10.1016/j.apsusc.2007. 01.075

${ }^{23}$ F. Bentiss, M. Lagrenee, M. Traisnel, Thermodynamic characterization of metal dissolution and inhibitor adsorption processes in mild steel/2,5-bis(n-thienyl)-1,3,4-thiadiazoles/hydrochloric acid system, Corrosion Science, 47 (2005) 12, 2915-2931, doi:10.1016/ j.corsci.2005.05.034

${ }^{24}$ M. A. Migahed, I. F. Nassar, Corrosion inhibition of tubing steel during acidization of oil and gas wells, Electrochimica Acta, 53 (2008) 6, 2877-2882, doi:10.1016/j.electacta.2007.10.070

${ }^{25}$ F. Bentiss, M. Lagrenee, M. Traisnel, J. C. Hornez, The corrosion inhibition of mild steel in acidic media by a new triazole derivative, Corrosion Science, 41 (1999) 4, 789-803, doi:10.1016/S0010938X(98)00153-X

${ }^{26}$ E. A. Flood, The solid-gas interface, Marcel Dekker, New York 1967,1690

${ }^{27}$ S. Brunauer, P. H. Emmett, E. Teller, Adsorption of gases in multimolecular layers, Journal of the American Chemical Society, 60 (1938) 2, 309-319, doi:10.1021/ja01269a023

${ }^{28}$ B. B. Damaskin, O. A. Petrii, V. V. Batrakov, Adsorption of Organic Compounds on Electrodes, Plenum Press, New York 1971, 500

${ }^{29}$ P. Loganathan, R. G. Burau, Sorption of heavy metal ions by a hydrous manganese oxide, Geochim. Geochimica et Cosmochimica Acta, 37 (1973) 5, 1277-1293, doi:10.1016/0016-7037(73)90061-6

${ }^{30} \mathrm{R}$. Parsons, The electrical variable and the form of the isotherm for the adsorption of organic compounds at electrodes, Journal of Electroanalytical Chemistry, 8 (1964) 2, 93-98, doi:10.1016/0022-0728 (64)87002-9

${ }^{31}$ A. N. Frumkin, Electrocapillary curve of higher aliphatic acids and the state equation of the surface layer, International Journal of Research in Physical Chemistry and Chemical Physics, 116 (1925), 466-488
${ }^{32}$ X. Li, S. Deng, G. Mu, H. Fu, F. Yang, Inhibition effect of nonionic surfactant on the corrosion of cold rolled steel in hydrochloric acid, Corrosion Science, 50 (2008) 2, 420-430, doi:10.1016/j.corsci. 2007.08.014

${ }^{33}$ K. F. Khaled, M. M. Al-Qahtani, The inhibitive effect of some tetrazole derivatives towards Al corrosion in acid solution: Chemical, electrochemical and theoretical studies, Materials Chemistry and Physics, 113 (2009) 1, 150-158, doi:10.1016/j.matchemphys.2008. 07.060

${ }^{34}$ Y. Qiang, S. Zhang, S. Xu, W. Li, Experimental and theoretical studies on the corrosion inhibition of copper by two indazole derivatives in $3.0 \% \mathrm{NaCl}$ solution, Journal of Colloid and Interface Science, 472 (2016), 52-59, doi:10.1016/j.jcis.2016.03.023

${ }^{35}$ H. H. Abdel-Rahman, A. M. Hafez, A. A. Helmy, Physicochemical study on the effectiveness of eco-friendly anti-corrosion agent on the corrosion of steel in $\mathrm{H}_{3} \mathrm{PO}_{4}$ solution, Electrochemistry, 83 (2015) 6 , 440-444, doi:10.5796/electrochemistry.83.440

${ }^{36}$ F. M. Donahue, K. Nobe, Theory of organic corrosion inhibitors: Adsorption and linear free energy relationships, Journal of The Electrochemical Society, 112 (1965) 9, 886-891, doi:10.1149/ 1.2423723

${ }^{37}$ F. Touhami, A. Aouniti, Y. Abed, Hammouti, B. S. Kertit, A. Ramdani, K. Elkacemi, Corrosion inhibition of armco iron in $1 \mathrm{M} \mathrm{HCl}$ media by new bipyrazolic derivatives, Corrosion Science, 42 (2000) 6, 929-940, doi:10.1016/S0010-938X(99)00123-7

${ }^{38}$ M. H. Wahdan, A. A. Hermas, M. S. Morad, Corrosion inhibition of carbon-steels by propargyltriphenylphosphonium bromide in $\mathrm{H}_{2} \mathrm{SO}_{4}$ solution, Materials Chemistry and Physics, 76 (2002) 2, 111-118, doi:10.1016/S0254-0584(01)00526-0

${ }^{39}$ E. Khamis, F. Bellucci, R. Latanision, E. El-Ashry, Acid corrosion inhibition of nickel by 2-(triphenosphoranylidene) succinic anhydride, Corrosion, 47 (1991) 9, 677-686, doi:10.5006/1.3585307

${ }^{40}$ S. Li, S. Chen, S. Lei, H. Ma, R. Yu, D. Liu, Investigation on some Schiff bases as $\mathrm{HCl}$ corrosion inhibitors for copper, Corrosion Science, 41 (1999) 7, 1273-1287, doi:10.1016/S0010-938X(98) 00183-8 